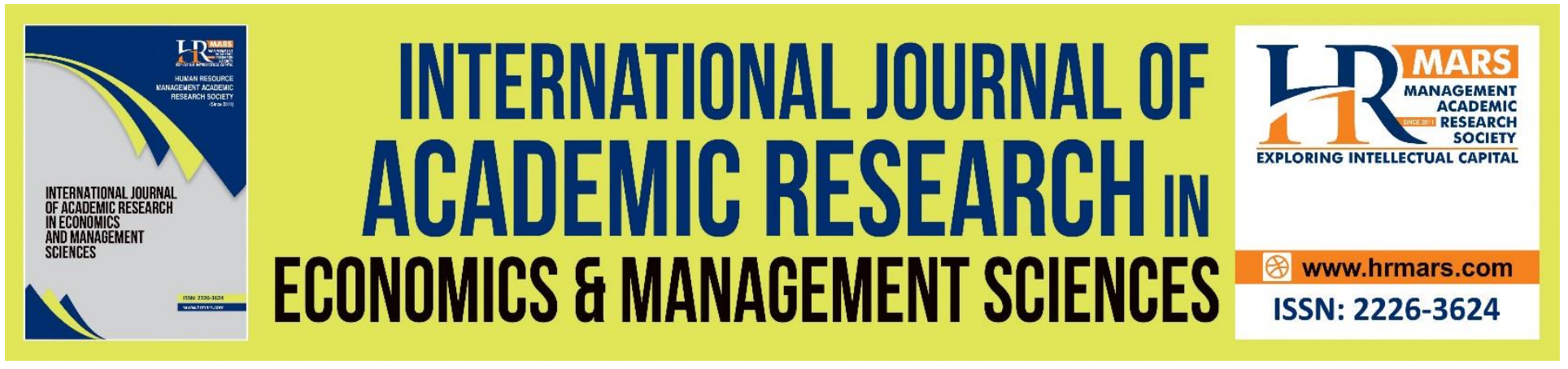

\title{
Which Type of Investments is Preferred to Achieve A Higher Economic Growth? A Case of the Upper-Middle-Income Economies
}

Nur Hayati Abd Rahman, Shafinar Ismail, Abd Rahim Ridzuan, Hazalinda Harun, Amizatul Hawariah Awang, Fariha Aiza Ramly

To Link this Article: http://dx.doi.org/10.6007/IJAREMS/v10-i1/8882

DOI:10.6007/IJAREMS/v10-i1/8882

Received: 12 January 2021, Revised: 09 February 2021, Accepted: 28 February 2021

Published Online: 26 March 2021

In-Text Citation: (Rahman et al., 2021)

To Cite this Article: Rahman, N. H. A., Ismail, S., Ridzuan, A. R., Harun, H., Awang, A. H., \& Ramly, F. A. (2021). Which Type of Investments is Preferred to Achieve A Higher Economic Growth? A Case of the UpperMiddle-Income Economies. International Journal of Academic Research in Economics and Managment and Sciences, 10(1), 153-169.

Copyright: ( 2021 The Author(s)

Published by Human Resource Management Academic Research Society (www.hrmars.com)

This article is published under the Creative Commons Attribution (CC BY 4.0) license. Anyone may reproduce, distribute, translate and create derivative works of this article (for both commercial and non-commercial purposes), subject to full attribution to the original publication and authors. The full terms of this license may be seen at: http://creativecommons.org/licences/by/4.0/legalcode

Vol. 10, No. 1, 2021, Pg. 153 - 169

Full Terms \& Conditions of access and use can be found at http://hrmars.com/index.php/pages/detail/publication-ethics 


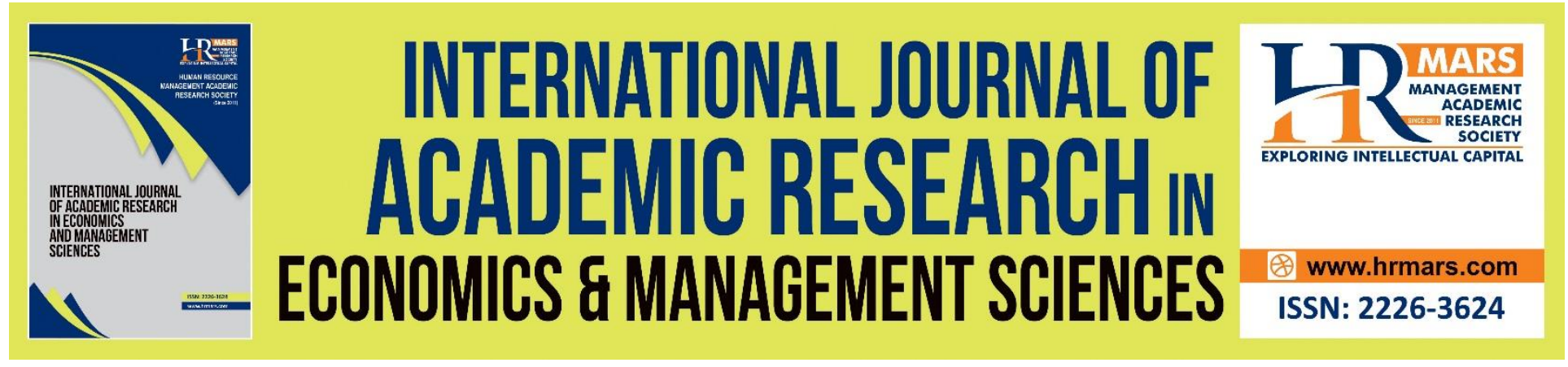

\title{
Which Type of Investments is Preferred to Achieve A Higher Economic Growth? A Case of the Upper-Middle-Income Economies
}

\author{
Nur Hayati Abd Rahman, Shafinar Ismail, Abd Rahim Ridzuan, \\ Hazalinda Harun, Amizatul Hawariah Awang, Fariha Aiza \\ Ramly \\ Universiti Teknologi MARA Cawangan Melaka, Melaka, Malaysia \\ Email: nurhayati.uitmt@gmail.com
}

\begin{abstract}
Industrial revolution 4.0 requires the upper-middle-income economies to invest in critical areas such as technological advancement, infrastructure, internet of things, research and development, and so on. However, as majority of these economies are falling into the middleincome trap, they need huge supports from domestic and foreign investors to supply capital for growth stimulation. The issue on which type of investment should the governments rely on is crucial as it might help the countries to move out from the middle-income trap position. By using system GMM on four different growth models, it was found that gross saving is the main contributor to the economic growth of the upper-middle-income economies. Rather than domestic and foreign investments, the governments should accumulate more savings for future growth and development, which can be used as a source of capital especially in the areas of human capital development, technology, research, Internet of Things, in-line with the needs of industrial revolution 4.0.
\end{abstract}

Keywords: Economic Growth, Foreign Direct Investment, National Savings, Domestic Investment, Upper-Middle-Income Economies

\section{Introduction}

In-line with the industrial revolution 4.0, higher amounts of public and private investments are required to develop new infrastructures, enhance the performance of existing industries and train existing labors in meeting the industrial demand. For sure, it requires countries to inject higher amount of funds for the agenda of economic transformation. The sources of funds may come from the government itself, in the forms of national savings and public debt. The government can also acquire funds by attracting local and foreign investors to invest in critical areas such as education, infrastructure, research and development as well as technological advancement. These types of investments are highly crucial to achieve competitive advantage, thus allowing the countries to achieve economies of scale and penetrate bigger market size through export and import. 


\section{SCIENCES}

Vol. 10, No. 1, 2021, E-ISSN: 2226-3624 @ 2021 HRMARS

Nevertheless, attracting new investors to invest in a country is not an easy task. The macroeconomic foundation must be stable and resilient enough to confront with any shocks. The investors would be interested to invest in countries with high economic growth since it gives them confident that their return on investments will always be positive and significant. However, previous statistics show that some countries under the upper-middle-income economies (UMIE) were unable to maintain high economic performance, leading to demotion of their status from UMIE to lower-middle-income economies (LMIE). By definition, countries classified under the UMIE receive gross national income (GNI) per capita ranging from $\$ 3,896$ to $\$ 12,055$, while the countries with LMIE status earned GNI per capita from $\$ 996$ to $\$ 3,895$ (The World Bank, 2018). As illustrated in Table 1.1, 13 out of 56 countries within the UMIE have experienced demotion to LMIE since 1990 to 2019. The years of demotion varies from one year (Albania, Jordan, Tonga and Turkey) to fifteen years (Romania).

Table 1: Countries within UMIE that have been downgraded into LMIE

\begin{tabular}{ccccc}
\hline No. & Countries & $\begin{array}{c}\text { Starting fiscal } \\
\text { years with UMIE's } \\
\text { classification }\end{array}$ & $\begin{array}{c}\text { Fiscal years demoted } \\
\text { into LMIE }\end{array}$ & $\begin{array}{c}\text { Fiscal years } \\
\text { retained back } \\
\text { to UMIE's } \\
\text { classification }\end{array}$ \\
\hline 1 & Albania & 2011 & $2013(1)$ & $2014-2019$ \\
\hline 2 & Belize & 2004 & $2010-2013(4)$ & $2014-2019$ \\
\hline 3 & Bostwana & 1993 & $1995-1998(4)$ & $1999-2019$ \\
\hline 4 & Brazil & 1991 & $2004-2007(4)$ & $2008-2019$ \\
\hline 5 & Fiji & 2009 & $2012-2013(2)$ & $2014-2019$ \\
\hline 6 & Republic of Iran & 1989 & $1992-2010(9)$ & $2011-2019$ \\
\hline 7 & Jordan & 2012 & $2018(1)$ & 2019 \\
\hline 8 & Romania & 1989 & $1992-2006(15)$ & $2007-2019$ \\
\hline 9 & South Africa & 1990 & $2000(1)$ & $2001-2002$ \\
\hline 10 & Suriname & 1989 & $2003-2005(3)$ & $2006-2019$ \\
\hline 11 & Tonga & 2014 & $1995-2008(14)$ & $2009-2019$ \\
\hline 12 & Turkey & 1999 & $2017(1)$ & $2018-2019$ \\
\hline 13 & Venezuela & 1989 & $2001(1)$ & 2002 \\
& & & $2003-2005(3)$ & $2006-2019$ \\
\hline
\end{tabular}

After all, Malaysia as one of the UMIE is able to maintain the status of UMIE since 1990 till now. However, our economic growth is still not increase at a promising rate, thus leading to a middle-income trap. It happens when the countries are trapping themselves in the UMIE for long-period of time, and struggling in transforming themselves from UMIE into HIE. This issue is also applicable to majority of the countries within the UMIE. Previous statistics show that only four countries within the UMIE are able to achieve GNI per capita more than $\$ 12,055$ since 1990, namely American Samoa, Equatorial Guinea, Russian Federation and Venezuela. For instance, Venezuela was able to achieve the HIE status in the fiscal year of 2016, before being demoted back to UMIE due to high inflation and macroeconomic instability. Similarly, Russian Federation was only able to achieve HIE status for three years (fiscal year of 2014 to 2016) since 2006. 


\section{SCIENCES}

Vol. 10, No. 1, 2021, E-ISSN: 2226-3624 @ 2021 HRMARS

Indirectly, it shows that the countries within the UMIE cannot use the same strategies to boost the level of economic growth as what they did when they were at the lower level of economic development. Applying the same strategies will lead to economic stagnation, thus leading to the middle-income trap (Bulman, Eden, \& Nguyen, 2017). Focusing too much on existing products without any invention and innovation will lead to economic stagnation as other countries started to produce similar products with better quality. It if happens, the countries may no longer retain their competitive advantage on the products, thus limiting their ability to grow further. In mitigating the problem, the needs of support from domestic and foreign investors are highly crucial for economic transformation agenda for all UMIE including Malaysia. The funds injected by these investors can be invested in critical areas parallel to the development of the IR4.0.

Therefore, this paper is meant to investigate which type of investment is the most crucial investment for UMIE to achieve higher economic growth. This issue is worth to be investigated since the investment is regarded as one of the critical success factors for the economic growth and development. The structure of this paper is as follows. The next section reviews previous studies on how investment affects economic growth. The reviews cover both theoretical and empirical aspects of investment on growth. Follow suit is the third chapter that explains the research design, research method and model specifications as well as variables used in the analyses. The fourth chapter discusses the empirical results and findings while the final chapter explains the conclusions and policy recommendations.

\section{Literature Review}

The Solow growth model which is built from the neoclassical aggregate production function (Solow, 1956), stress three main causes of economic growth namely capital, labor and technology. These three resources are complementary to each other. A labor is able to produce more outputs if he is assisted by additional capital. However, any additional capital injected in the production process will have a diminishing return to the labor productivity (Snowdon \& Vane, 2005). Therefore, the usage of capital in the production process will contribute the most to the economic growth when the capital itself is relatively scarce. In opposite, if the capital is relatively abundant in the economy, its impact on the economic growth may not be at the optimum level due to the diminishing return.

In an open economy, capital mobility across countries is possible. The countries with relatively abundant capital will be attracted to invest in other countries that give higher returns, thus accelerating the process of capital accumulation in the countries that have relatively scarce capital. Ultimately, countries with scarce capital can still achieve higher economic growth via the role of capital mobility.

Similarly, the endogenous growth model which was developed to overcome the weaknesses of the Solow growth model, agreed on the importance of capital to stimulate economic growth. Higher capital leads to better technological improvement. In the Solow growth model, Solow (1956) believes that the technological improvement is exogenous across countries. In other words, all countries have the same level of technological improvement as it is publicly available for free. Nevertheless, in the endogenous growth model, the technological improvement is considered as endogenous (Lucas, 1988; Romer, 1986). Each country has different level of technological improvement due to different abilities to absorb 


\section{SCIENCES}

Vol. 10, No. 1, 2021, E-ISSN: 2226-3624 ㄷ 2021 HRMARS

the knowledge. Thus, it is said that higher capital leads to improvement in technology and production of knowledge, which ultimately helps in stimulating the economic growth of a country. This is the main contribution of the endogenous growth model, which also highlights the importance of human capital in the growth literature. In this case, better human capital is developed due to the technological improvement which comes from the utilization of capital.

Empirically, a lot of research have been done on how capital investment affects the economic growth. The capital investment comes in various forms such as national savings (Mencinger, Verbic, \& Aristovnik, 2015; Sulikova, Djukic, Gazda, Horvath, \& Kulhanek, 2015), domestic investment (Akram, 2016; Gómez-Puig \& Sosvilla-Rivero, 2018b) and foreign direct investment (Chirwa \& Odhiambo, 2016; Fashina, Asaleye, Ogunjobi, \& Lawal, 2018). No doubt that all of these capital investments bring prosperity and growth. For instance, domestic investment positively influenced the economic growth of Vietnam and selected Asian countries due to the effectiveness of the strategies in promoting the inflows of domestic investment (Bakari \& Tiba, 2019). Similarly, by applying various types of methodologies such as two-stage least square (Akhanolu, Babajide, Victoria, Tolulope, \& Godswill, 2018; Chirwa \& Odhiambo, 2016; Dao, 2018), ordinary least square (Rana \& Wahid, 2017) and system GMM (Kim, Ha, \& Kim, 2017), the results confirmed the positive effect of domestic capital investment on economic growth.

With regards to FDI as a source of capital, it gives positive multiplier effect to the economic growth in the cases of Malaysia (Alzaidy et. al., 2017), Korea (Kim \& Pang, 2008) and Pakistan (Shahbaz \& Rahman, 2012). It is mainly due to the knowledge spillover from the multinational companies to local businesses that indirectly support the domestic economic growth. By combining both arguments from domestic and foreign investments, both types of investment generate higher capital that helps to increase purchasing power of people via new employment opportunities. Higher consumptions and investment would then increase the economic growth of the countries.

Even though vast studies have found positive relationship between capital and economic growth, there were also studies that found otherwise. For instance, Thailand's domestic investment was found to adversely affect the economic growth from 1975 to 2018. The reason being is because of the ineffectiveness of the domestic investment on projects and activities that give lesser positive impacts to the economy (Raza, Aldeehani \& Alshebami, 2020). By looking at previous literature, most of the studies were conducted on one specific country or a group of economies. Besides, previous research looked at the positive or negative effect brought by each different type of capital investment. Nevertheless, lack of studies has been conducted on how each type of these capital investments affect economic growth, specifically for the UMIE. Which one should the government focus on to strive for higher economic growth? This paper is meant to contribute to the existing literature by covering this loophole.

\section{Methodology}

The foundation of the growth model is based on the Cobb-Douglas production function. It can be written as follows: 


\section{SCIENCES}

Vol. 10, No. 1, 2021, E-ISSN: 2226-3624 ㄷ 2021 HRMARS

$Y=K^{\alpha} L^{1-\alpha}$

(1)

where $Y$ is the aggregate output, $K$ is the capital, $L$ is the labor while $\alpha$ and 1- $\alpha$ are both representing the share of capital and labor in the national income. In this paper, we use three types of capital as previously discussed in past literature namely national savings (SAV), domestic investment (INV2) and foreign direct investment (FDI). Apart from K and L, other variables are also included in the growth model namely human capital (HC), trade openness (TO) and inflation (INF). Firstly, HC is included consistent with the endogenous growth model that highlights its importance. Secondly, TO is also included to represent the open economy that the countries within the UMIE are practicing. Thirdly, INF is added to indicate the macroeconomic stability of each country under investigation. Finally, the log of initial real GDP per capita $\left(\operatorname{In} Y_{i 0}\right)$ is included to illustrate how countries within the UMIE converge to the steady state of the equilibrium level (Islam, 1995). By combining all variables, the baseline model specification is written as follows:

$\ln Y_{i t}=\alpha_{i}+\beta_{1} \operatorname{lnGDPPC} C_{i, t}+\beta_{2} \ln L_{i t}+\beta_{3} \ln K_{i t}+\beta_{4} \ln H C_{i t}+\beta_{5} \ln \operatorname{lO}_{i t}+\beta_{6} \ln I N F_{i t}+\varepsilon_{i t}$

(2)

where $Y$ is the GDP growth representing, $i$ is cross section, $t$ is time, $\alpha$ is a constant term, $\beta$ is the coefficient for each variable and $\varepsilon$ is the error term. The variable under investigation is $K$ (capital). It represents three types of capital namely SAV, INV and FDI. Meanwhile, the remaining variables (L, HC, TO and INF) are regarded as the control variables.

In order to ensure the robustness of the estimation results, four models were formed. The first three models include each and every type of capital separately, while the fourth model combines all types of capital in the same equation. All four models are shown in equation (3) to (6).

$$
\begin{aligned}
& \ln Y_{i t}=\alpha_{i}+\beta_{1} \ln Y_{i 0}+\beta_{2} \ln L_{i t}+\beta_{3} \ln S A V_{i t}+\beta_{6} \ln H C_{i t}+\beta_{7} \operatorname{lnTO} O_{i t}+\beta_{5} \ln I N F_{i t}+\varepsilon_{i t} \\
& \ln Y_{i t}=\alpha_{i}+\beta_{1} \ln Y_{i 0}+\beta_{2} \ln L_{i t}+\beta_{4} \ln I N V 2_{i t}+\beta_{6} \operatorname{lnHC} C_{i t}+\beta_{7} \operatorname{lnTO} O_{i t}+\beta_{5} \ln I N F_{i t}+\varepsilon_{i t} \\
& \ln Y_{i t}=\alpha_{i}+\beta_{1} \ln Y_{i 0}+\beta_{2} \ln L_{i t}+\beta_{5} \ln F_{1} I_{i t}+\beta_{6} \ln H C_{i t}+\beta_{7} \ln \mathrm{O}_{i t}+\beta_{5} \ln I N F_{i t}+\varepsilon_{i t} \\
& \ln Y_{i t}=\alpha_{i}+\beta_{1} \ln Y_{i 0}+\beta_{2} \ln L_{i t}+\beta_{3} \ln S A V_{i t}+\beta_{4} \ln I N V 2_{i t}+\beta_{5} \operatorname{lnFDI} I_{i t}+\beta_{6} \ln H C_{i t}+\beta_{7} \ln \operatorname{lO}_{i t}+
\end{aligned}
$$
$\beta_{5} \operatorname{lnINF} F_{i t}+\varepsilon_{\text {it }}$

(6) 


\section{SCIENCES}

Vol. 10, No. 1, 2021, E-ISSN: 2226-3624 ㄷ 2021 HRMARS

\section{Description and sources of the data}

The description and the sources of the data are explained in Table 2.

Table 2: The description and the sources of data

\begin{tabular}{|c|c|c|c|c|c|}
\hline No. & $\begin{array}{l}\text { Variable } \\
\text { Notation }\end{array}$ & $\begin{array}{l}\text { Variable } \\
\text { Name }\end{array}$ & Description & $\begin{array}{c}\text { Measurement } \\
\text { Unit }\end{array}$ & Sources \\
\hline 1 & $\ln Y$ & $\begin{array}{l}\text { Economic } \\
\text { growth }\end{array}$ & $\begin{array}{c}\text { Growth rate of GDP } \\
\text { per capita }\end{array}$ & Percentage & $\begin{array}{l}\text { World Development } \\
\text { Indicator }\end{array}$ \\
\hline 2 & $\ln Y_{i 0}$ & $\begin{array}{l}\text { Lagged of } \\
\text { initial } \\
\text { income }\end{array}$ & $\begin{array}{c}\text { Log of initial real GDP } \\
\text { per capita }\end{array}$ & Logarithm & $\begin{array}{l}\text { World Development } \\
\text { Indicator }\end{array}$ \\
\hline 3 & $\ln \mathrm{L}$ & Labour & Population growth & Percentage & $\begin{array}{l}\text { World Development } \\
\text { Indicator }\end{array}$ \\
\hline 4 & InSAV & $\begin{array}{c}\text { Domestic } \\
\text { savings }\end{array}$ & $\begin{array}{l}\text { Gross domestic } \\
\text { savings to GDP }\end{array}$ & Percentage & $\begin{array}{l}\text { World Development } \\
\text { Indicator }\end{array}$ \\
\hline 5 & LnINV2 & $\begin{array}{c}\text { Domestic } \\
\text { investment }\end{array}$ & $\begin{array}{c}\text { Gross capital } \\
\text { formation to GDP }\end{array}$ & Percentage & $\begin{array}{l}\text { World Development } \\
\text { Indicator }\end{array}$ \\
\hline 6 & InFDI & $\begin{array}{c}\text { Foreign } \\
\text { direct } \\
\text { investment }\end{array}$ & $\begin{array}{c}\text { Net inflows of FDI to } \\
\text { GDP }\end{array}$ & Percentage & $\begin{array}{l}\text { World Development } \\
\text { Indicator }\end{array}$ \\
\hline 7 & $\mathrm{InHC}$ & $\begin{array}{c}\text { Human } \\
\text { capital }\end{array}$ & Human capital index & Index & Penn World Table \\
\hline 8 & InTO & $\begin{array}{c}\text { Trade } \\
\text { openness } \\
\end{array}$ & $\begin{array}{c}\text { Sum of export and } \\
\text { import to GDP }\end{array}$ & Percentage & $\begin{array}{l}\text { World Development } \\
\text { Indicator }\end{array}$ \\
\hline 9 & InINF & Inflation & Consumer price index & Percentage & $\begin{array}{l}\text { World Development } \\
\text { Indicator }\end{array}$ \\
\hline
\end{tabular}

All variables were derived from World Development Indicator database by the World Bank, except for HC. The data on HC is gathered from Penn World Table. It is calculated based on the years of schooling and returns to education (Feenstra, Inklaar, \& Timmer, 2015).

\section{Scope of Study}

The scope of this study is covering on the countries within the UMIE only since majority of these countries are in the middle-income trap. Out of 56 countries in the UMIE, only 32 countries were selected due to data availability. The list of countries under investigation is shown in the Appendix 1. The period of study is from 1990 to 2017. Since the impact of investment on growth can only be realized after few years, the data were averaged into nonoverlapping five-year period, leading to six time period. Following previous research (Karadam, 2018), the averaging procedure is conducted for two reasons. Firstly, we want to look at the long-run effects since the effects of investment cannot be realized on the same year. Secondly, the averaging procedure is initiated to avoid any structural break in the data that might influence the estimation results.

\section{Method of Analyses}

The first step in analyzing the data is by conducting the correlation analysis. The idea is to ensure all independent variables are free from multicollinearity problem. The next step is to remove any outliers in the models in order to ensure accuracy of the estimation results. To 


\section{SCIENCES}

Vol. 10, No. 1, 2021, E-ISSN: 2226-3624 ㄷ 2021 HRMARS

do so, Cook's D test is conducted to all four models. The test is done by calculating the cutoff distance (divide 4 with the number of observations). Since the number of observations is 189 , any observations with cutoff distance more than 0.021 are considered as outliers. These outliers will be removed to ensure better accuracy of the results.

Once the outliers are removed, the selection of the right method for panel data estimation should be based on the number of time and cross sections. Since we have large cross sections (32 countries) but small time period $(t=6)$, the appropriate method is the generalized method of moments (GMM). Apart from that, this method is also suitable as it is able to manage endogeneity issue in the set of the independent variables (Arellano \& Bond, 1991). The endogeneity issue exists for our model because some of the independent variables can be the dependent variable at the same time. For instance, higher economic growth is one of the factors that can increase the domestic and foreign investors in the countries. In this regard, INV2 and FDI can be dependent variables against GDPG. Following previous growth literature, all variables in the growth models are treated as endogenous variables (Cieślik \& Goczek, 2018). This issue cannot be tackled by using traditional panel estimators such as pooled ordinary least square, fixed effects and random effects model (Zhang, Hao, Lu, \& Deng, 2018). Instead, it can be solved using GMM estimation method by adding lagged levels of regressors as the instrumental variables. In between system GMM and difference GMM, system GMM is more preferable since it is able to reduce biases and provide better estimation results (Blundell \& Bond, 1998). Hence, this study uses system GMM to gather the estimation results.

The results from system GMM will only be valid if two conditions are met. Firstly, there should be no serial correlation in the error terms at the second order. It is tested by using ArellanoBond test, with a null hypothesis of no serial correlation in the error terms at second order. Secondly, the instruments should be exogenous (Hansen, 1982). In this case, Hansen J test is conducted to ensure that the null hypothesis is not rejected (overidentifying restrictions are valid).

\section{Empirical Results and Discussion}

The results of the descriptive statistics for all variables used in this paper are tabulated in Table 3. As illustrated in Table 3, the minimum and the maximum values for all variables show an increasing trend. Besides, the mean and median for all variables are closer to each other except for INF. Besides, there are huge differences between the minimum and maximum values of TO and INF. The two symptoms indicate the existence of outliers as the data might have extreme values. 
Table 3: Descriptive Statistics

\begin{tabular}{ccccccc}
\hline No. & Variable & Mean & Median & $\begin{array}{c}\text { Standard } \\
\text { Deviation }\end{array}$ & Minimum & Maximum \\
\hline 1 & $\mathrm{Y}$ & 2.324726 & 2.183728 & 3.15748 & -12.57597 & 11.27283 \\
2 & $\mathrm{Y}_{\mathrm{iO}}$ & 8.521685 & 8.505189 & 0.5431781 & 6.591894 & 9.536264 \\
3 & $\mathrm{~L}$ & 1.177353 & 1.309962 & 1.135407 & -1.505077 & 5.207555 \\
4 & SAV & 22.46649 & 20.69014 & 13.337 & -28.03556 & 56.01711 \\
5 & INV2 & 24.67995 & 23.30981 & 6.63747 & 12.66405 & 49.99508 \\
6 & FDI & 3.043388 & 2.59497 & 2.672332 & -4.17289 & 18.91545 \\
7 & HC & 2.526 & 2.558554 & 0.4273671 & 1.467674 & 3.489187 \\
8 & TO & 72.05042 & 64.61259 & 33.63603 & 15.56648 & 205.5394 \\
9 & INF & 1290.627 & 6.8966 & 16878.62 & -0.121 & 232662.3 \\
\hline
\end{tabular}

Apart from that, the correlation analysis as tabulated in Table 4 show no multicollinearity problem exists since the correlation values between all independent variables did not exceed 0.8. Thus, all independent variables can be included in the models.

Table 4: Correlation Analysis

\begin{tabular}{c|ccccccccc}
\hline & $\mathrm{Y}$ & $\mathrm{Y}_{\mathrm{i} 0}$ & $\mathrm{TO}$ & $\mathrm{L}$ & $\mathrm{HC}$ & INF & SAV & INV2 & FDI \\
\hline $\mathrm{Y}$ & 1.0000 & & & & & & & & \\
$\mathrm{Y}_{\mathrm{i} 0}$ & - & 1.0000 & & & & & & & \\
& 0.2453 & & & & & & & & \\
TO & 0.0260 & -0.0551 & 1.0000 & & & & & \\
L & - & 0.0782 & 0.1217 & 1.0000 & & & & & \\
& 0.2003 & & & & & & & & \\
HC & 0.1071 & 0.1240 & 0.2581 & -0.4813 & 1.0000 & & & & \\
INF & - & -0.1107 & - & -0.1700 & 0.0218 & 1.0000 & & & \\
& 0.4422 & & 0.0063 & & & & & & \\
SAV & 0.1175 & 0.3455 & 0.0489 & 0.2037 & -0.1882 & -0.1029 & 1.0000 & & \\
INV2 & 0.3015 & -0.1294 & 0.0953 & 0.0398 & -0.1258 & -0.0287 & 0.5505 & 1.0000 & \\
FDI & 0.2758 & -0.0346 & 0.2885 & -0.1624 & 0.4709 & -0.1167 & -0.2162 & 0.0279 & 1.0000 \\
\hline
\end{tabular}

As illustrated in Appendix 2, the scatter plots in between INV2, SAV and FDI against Y prove the existence of outliers in the dataset especially for observations that belong to Armenia, Kazakhstan, Albania and Russian Federation. After calculating the cutoff distance using Cook's $D$ test, few observations were found to be outliers. All of these observations were removed following suggestion by previous research (Law, 2018).

\section{Main Results}

Table 5 illustrates the results of the two-step system GMM for all four models. The results are highly consistent for all four models, indicating the robustness of the findings. Firstly, the LGDPPC as the convergence variable, meet the expected negative sign (Barro, 1991; Barro \& Sala-i-Martin, 2004) with coefficients ranging from -1.626 to -3.485 . Secondly, all investment variables have positive relationship with GDPG in all four models (Fashina et al., 2018; Pegkas, 2018), with FDI as the highest contributor to the economic growth. Thirdly, the signs of all control variables are parallel with previous literature, with negative sign for $L$ (Kharusi \& 


\section{SCIENCES}

Vol. 10, No. 1, 2021, E-ISSN: 2226-3624 ㄷ 2021 HRMARS

Mbah, 2018) and INF (Arčabić, Tica, Lee, \& Sonora, 2018), and positive sign for HC (Karadam, 2018) and TO (Fashina et al., 2018). Finally, the p-values for both AR(2) and Hansen test suggest that the model is correctly specified and the instruments are valid.

Besides, the most important source of growth for the UMIE is human capital. In all four models (1.1 to 1.4), the coefficients of the HC are the largest (excluding the convergence variable), ranging from 0.999 (in model 1.2) to 1.484 (in model 1.3). It indicates that the increase in the years of schooling generate higher returns to education and create pool of talents that can contribute to the economic growth in a long period of time (Ali, Egbetokun, $\&$ Memon, 2018). No doubt that education creates innovative mindset and forms a better quality of human capital and entrepreneurs. Within the four models, the coefficient of the HC is the highest when FDI is included in the model (model 1.4). Thus, it gives strong signal on the importance of FDI in accumulating capital, building human capital and achieving higher economic growth.

Before discussing the roles of investments on the economic growth, it is worth to look at the convergence variable denotes by LGDPPC. Consistent with the conditional convergence hypothesis, the coefficients of this variable are negative and significant in all four models (Barro \& Sala-i-Martin, 2004; Karadam, 2018). The convergence hypothesis claims that the developing countries are able to grow faster than the developed economies due to diffusion of technology and lower costs of product imitation. In this case, the UMIE are able to converge to the steady state of the development path at a high growth rate relative to the developed countries. However, as the countries converge to their steady state of the development path, other countries will start to catch-up with the development via product imitation and technological diffusion that can be obtained mainly from the FDI. 


\section{SCIENCES}

Vol. 10, No. 1, 2021, E-ISSN: 2226-3624 ㄷ 2021 HRMARS

Table 5: Panel data estimation using two-step system GMM

\begin{tabular}{|c|c|c|c|c|}
\hline & $\begin{array}{l}\text { (1.1) } \\
\text { Model with } \\
\text { InSAV }\end{array}$ & $\begin{array}{c}\text { (1.2) } \\
\text { Model with } \\
\text { InINV2 }\end{array}$ & $\begin{array}{c}\text { (1.3) } \\
\text { Model with } \\
\text { InFDI }\end{array}$ & $\begin{array}{c}\text { (1.4) } \\
\text { Model with } \\
\text { InSAV, InINV2 } \\
\& \text { InFDI }\end{array}$ \\
\hline & Coefficient & Coefficient & Coefficient & Coefficient \\
\hline$Y_{i 0}$ & $\begin{array}{l}-0.1597 * * * \\
(0.043)\end{array}$ & $\begin{array}{l}-0.1613 * * * \\
(0.028)\end{array}$ & $\begin{array}{c}-0.1434 * * * \\
(0.0435)\end{array}$ & $\begin{array}{c}-0.1359 * * * \\
(0.0 .0)\end{array}$ \\
\hline $\ln L$ & $\begin{array}{c}-0.1658 * * * \\
(0.053)\end{array}$ & $\begin{array}{c}-0.1653 * * * \\
(0.050)\end{array}$ & $\begin{array}{c}-0.1239 * * * \\
(0.034)\end{array}$ & $\begin{array}{c}-0.2666 * * * \\
(0.045)\end{array}$ \\
\hline $\ln \mathrm{HC}$ & $\begin{array}{c}0.3695^{* *} \\
(0.173)\end{array}$ & $\begin{array}{c}0.1794^{* *} \\
(0.093)\end{array}$ & $\begin{array}{c}0.1476 \\
(0.1218)\end{array}$ & $\begin{array}{r}-0.0843 \\
(0.128)\end{array}$ \\
\hline InINF & $\begin{array}{c}-0.0554 * * * \\
(0.015)\end{array}$ & $\begin{array}{c}-0.0688 * * * \\
(0.008)\end{array}$ & $\begin{array}{c}-0.0708 * * * \\
(0.016)\end{array}$ & $\begin{array}{c}-0.0696 * * * \\
(0.015)\end{array}$ \\
\hline $\ln T O$ & $\begin{array}{l}0.1693 * * * \\
(0.035)\end{array}$ & $\begin{array}{c}0.0709 * \\
(0.039)\end{array}$ & $\begin{array}{l}0.2432 * * * \\
(0.048)\end{array}$ & $\begin{array}{l}-0.0549 \\
(0.051)\end{array}$ \\
\hline InSAV & $\begin{array}{c}0.2471^{* * *} \\
(0.068)\end{array}$ & & & $\begin{array}{c}0.2237^{* * *} \\
(0.024)\end{array}$ \\
\hline InINV2 & & $\begin{array}{c}0.2092^{* * *} \\
(0.030)\end{array}$ & & $\begin{array}{c}0.2030^{* *} \\
(0.075)\end{array}$ \\
\hline InFDI & & & $\begin{array}{c}0.0806 * * * \\
(0.023)\end{array}$ & $\begin{array}{c}0.0773^{*} \\
(0.042)\end{array}$ \\
\hline Constant & $\begin{array}{c}2.3929 * * * \\
(0.407)\end{array}$ & $\begin{array}{c}3.3315^{* * *} \\
(0.3233)\end{array}$ & $\begin{array}{c}2.9352 * * * \\
(0.294)\end{array}$ & $\begin{array}{c}2.9840 * * * \\
(0.331)\end{array}$ \\
\hline Observations & 181 & 181 & 181 & 180 \\
\hline Number of countries & 32 & 32 & 32 & 32 \\
\hline No. of instruments & 26 & 28 & 29 & 27 \\
\hline $\begin{array}{l}\text { Arellano-Bond test for } \mathrm{AR}(2) \\
\qquad(p \text {-value) }\end{array}$ & 0.091 & 0.117 & 0.128 & 0.071 \\
\hline Hansen ( $p$-value) & 0.164 & 0.240 & 0.398 & 0.178 \\
\hline
\end{tabular}

Notes:

1. $* * *, * *$ and $*$ indicate $1 \%, 5 \%$ and $10 \%$ significant level respectively.

2. Values in parentheses are the standard errors.

\section{Discussion on InSAV to Economic Growth}

In between all types of capital investments, InSAV is the highest contributor to the economic growth due to its largest coefficient relative to InINV2 and InFDI. Parallel to previous studies (Gómez-Puig \& Sosvilla-Rivero, 2018a), similar positive finding can be seen from the gross savings with the coefficient value of 0.2471 (model 1.1) and 0.2237 (model 1.4). It implies the deepening of the financial development in the UMIE, which assist the countries to increase their wealth and accumulate higher savings for future development (Grigoli, Herman, \& Schmidt-Hebbel, 2018). Moreover, a significant positive relationship between InSAV and InY illustrates that the countries are channelling their savings for investment in productive purposes, thus boosting the economic growth (Wan Azman Saini, 2009). 


\section{SCIENCES}

Vol. 10, No. 1, 2021, E-ISSN: $2226-3624$ @ 2021 HRMARS

Apart from that, gross savings lead to higher economic growth especially when the economy is facing with lower macroeconomic instability (Grigoli et al., 2018). In order to prove this statement, we should look at the coefficient of the InINF since it measures the macroeconomic instability. By observing the models with InSAV (model 1.1 and 1.4), InINF has the lowest coefficients in both models with -0.0554 and -0.0696 respectively. Even though the signs of InINF in both models are negative, the coefficient is very low. It indicates that the macroeconomic instability in the UMIE were under control. It gives good sign for the private sector to consume and invest more, thus playing the role as the engine of growth. The private sector's contribution helps the government to save more and invest the funds in productive expenditures, then contributing to the national growth and development.

If the gross savings are used for unproductive or corrupted purposes, it might not help in increasing the economic growth of a country. It is proven statistically, in which Gabon has the highest percentage of average gross savings to GDP from 1990 to 2019 (49.06 percent). Nevertheless, in 2018, Gabon was considered as among the corrupted countries (Transparency International, 2018) since the corruption perception index was close to 0 (scored at 31 out of 100). As a note, the score is ranging from 0 (highly corrupted country) and 100 (the cleanest country in terms of corruption). Due to misallocation or mismanagement of funds particularly from gross savings, the average GDP growth per capita was at the lowest level (-0.568 percent) as compared to the other UMIE (refer Error! Reference source not found.). However, when combining all other UMIE into the panel data analysis, InSAV still gives positive effects to $\ln Y$ despite a special case for Gabon.

\section{Discussion on InINV2 to Economic Growth}

As a measure of domestic investment, InINV2 is proven to have positive relationship with InY. It is shown in the coefficients of InINV2 in model 1.2 and 1.4, with 0.2092 and 0.2030 , respectively. By comparing model 1.1 and model 1.2, InINV2 is having a similar role relative to InSAV in influencing InY due to similar coefficient (0.2). One possible reason is due to the ability of the domestic investment in generating new employment opportunities to the public. An increase in the number of jobs will not just increase the purchasing power of the people. It is also helpful in reducing the poverty and income inequality, as well as increasing the growth of the country via higher private consumptions.

Moreover, the positive relationship postulates higher domestic investment have been channelled to research and development (R\&D), technological progress and other productive purposes, which in turn leads to an increase in the productivity growth of the countries (Dao, 2018). Higher productivity will motivate the private sector to produce more goods and services at a lower cost, thus increasing the demand for labour. As long as the investment is supported by technological progress, UMIE will be capable in creating new knowledge and technology by combining both capital and skilled labours efficiently. This, in turn, will gives value added to the economic growth of the UMIE.

Nonetheless, the coefficient of InINV2 in model $1.4(0.2030)$ is lower than the coefficient of the same variable in model $1.2(0.2092)$. It indicates that the contribution of the domestic investment is declining when the UMIE is also relying on the foreign investment as a source of growth. It might be due to fierce competition that domestic investors have to embrace as the foreign investors are normally equipped with far better technological progress (Krstevska 


\section{SCIENCES}

Vol. 10, No. 1, 2021, E-ISSN: 2226-3624 ㄷ 2021 HRMARS

\& Petrovska, 2012). Even so, this competition is good for the economic growth since the domestic and foreign investors can learn from each other, sharing expertise and transferring knowledge to ensure better growth.

\section{Discussion on InFDI to Economic Growth}

The result for InFDI is in agreement with our expectation. In achieving high economic growth, the UMIE needs to attract more investments from abroad, especially in relation to hightechnology, digitalization and so on. High inflow of FDI would in turn, leads to a better human capital development due to transfer of skills, knowledge and technology that are deemed essential for economic transformation. The spill over from the FDI is transferred into the human capital investment in the forms of training, thus further helps the UMIE to achieve higher economic growth.

Consistent with previous research, the positive effect of InFDI is partly contributed by the level of trade openness of a country (Akram, 2016; Jayasuriya, 2011). It can be shown by looking at the significant coefficient of the InTO in the third model, amounting to 0.2432 . As countries within the UMIE are willing to involve more in trade and partnership with the rest of the countries, the trade activities help them to receive valuable technology and expertise from abroad via the roles of FDI, thus boosting the productivity of the country.

\section{Conclusion}

The most relevant conclusions are as follows. Firstly, the economic growth of the UMIE is positively depends on both domestic (InSAV and InINV2) and foreign investments (InFDI). When combining all the three investment variables into a model (model 1.4), InSAV is the most contributing factor in achieving high economic growth, followed by InINV2 and InFDI.

Secondly, since human capital is proven to be the most important factor influencing the economic growth (in model 1.1 and 1.2), the countries within the UMIE should invest more on the human capital to ensure their labours are able to generate new ideas, knowledge and technology that are essential for future economic growth. Besides, high reliance on the foreign investors might be the right decision if they want to achieve a high-income nation. It is because FDI assists in human capital development through the transfer of knowledge, expertise as well as technological advancement. In this case, the governments should attract more FDI into the countries by introducing or enhancing the current tax incentives. Besides, the institutional and business environments' quality should be preserved to ensure rapid inflows of FDI to the countries. This is important as the foreign capital, expertise and technological advancement from other countries can help the UMIE to move out from the middle-income trap, hence uplift their status into HIE while implementing the IR4.0 successfully. Sole reliance on domestic investment and domestic savings are insufficient for that matter.

This paper contributes empirically to the body of knowledge by integrating all three types of investment into the endogenous growth model. Theoretically, as all of these investments are positively contributed to the economic growth and development, their contribution might vary for a country or a group of economies. For instance, this research found that the FDI is not the most significant contributor to the economic growth for the UMIE even though it gives positive multiplier effects to the countries in the forms of technological and knowledge 


\section{SCIENCES}

Vol. 10, No. 1, 2021, E-ISSN: 2226-3624 @ 2021 HRMARS

transfer. Instead, the UMIE should utilizes more of their domestic capital (in the forms of SAV and INV2) to further boost the economic growth.

\section{References}

Akhanolu, I. A., Babajide, A. A., Victoria, A., Tolulope, O., \& Godswill, O. (2018). The effect of public debt on economic growth in Nigeria: An empirical investigation. International Business Management, 12(6), 436-441. https://doi.org/10.18488/journal.aefr/2016.6.11/102.11.692.705

Akram, N. (2016). Public debt and pro-poor economic growth evidence from South Asian countries. Economic Research-Ekonomska Istrazivanja, 29(1), 746-757. https://doi.org/10.1080/1331677X.2016.1197550

Ali, M., Egbetokun, A., \& Memon, M. H. (2018). Human capital, social capabilities and economic growth. Economies2, 6(2), 1-18.

Arčabić, V., Tica, J., Lee, J., \& Sonora, R. J. (2018). Public debt and economic growth conundrum: Nonlinearity and inter-temporal relationship. Studies in Nonlinear Dynamics and Econometrics, 22(1), 1-20. https://doi.org/10.1515/snde-2016-0086

Arellano, M., \& Bond, S. (1991). Some tests of specification for panel data: Monte Carlo evidence and an application to employment equations. The Review of Economic Studies, 58(2), 277-297. https://doi.org/10.2307/2297968

Bakari, S., \& Tiba, S. (2019). The impact of trade openness, foreign direct investment and domestic investment on economic growth: New evidence from Asian developing countries. MPRA Paper No. 94489. Retrieved from https://mpra.ub.unimuenchen.de/94489/.

Barro, R. J. (1991). Economic growth in a cross section of countries. Quarterly Journal of Economics.

Barro, R. J., \& Sala-i-Martin, X. (2004). Economic Growth. The MIT Press (2nd editio). England: The MIT Press. https://doi.org/10.1016/0025-5408(96)80018-3

Bulman, D., Eden, M., \& Nguyen, H. (2017). Transitioning from low-income growth to highincome growth: Is there a middle-income trap? Journal of the Asia Pacific Economy, 22(1), 1-5.

Chirwa, T. G., \& Odhiambo, N. M. (2016). Macroeconomic determinants of economic growth: A review of international literature. South East European Journal of Economics and Business, 11(2), 33-47. https://doi.org/10.1515/jeb-2016-0009

Cieślik, A., \& Goczek, Ł. (2018). Control of corruption, international investment, and economic growth - Evidence from panel data. World Development, 103, 323-335. https://doi.org/10.1016/j.worlddev.2017.10.028

Dao, M. Q. (2018). Tests of a more comprehensive model of economic growth in lower middle-income countries. Journal of Economic Studies, 45(1), 46-58. https://doi.org/10.1108/JES-12-2016-0257

Fashina, O. A., Asaleye, A. J., Ogunjobi, J. O., \& Lawal, A. I. (2018). Foreign aid, human capital and economic growth nexus: Evidence from Nigeria. Journal of International Studies, 11(2), 104-117. https://doi.org/10.14254/2071-8330.2018/11-2/8

Feenstra, R. C., Inklaar, R., \& Timmer, M. P. (2015). The next generation of the Penn World Table. American Economic Review, 105(10), 3150-3182.

Gómez-Puig, M., \& Sosvilla-Rivero, S. (2018a). Nonfinancial debt and economic growth in euro-area countries. Journal of International Financial Markets, Institutions and Money, 56, 17-37. https://doi.org/10.1016/j.intfin.2018.03.005 


\section{SCIENCES}

Vol. 10, No. 1, 2021, E-ISSN: 2226-3624 ๑ 2021 HRMARS

Gómez-Puig, M., \& Sosvilla-Rivero, S. (2018b). On the time-varying nature of the debtgrowth nexus: Evidence from the euro area. Applied Economics Letters, 25(9), 597-600. https://doi.org/10.1080/13504851.2017.1349284

Grigoli, F., Herman, A., \& Schmidt-Hebbel, K. (2018). Saving in the world. World Development, 104, 257-270. https://doi.org/10.1016/j.worlddev.2017.11.022

Islam, N. (1995). Growth empirics: A panel data approach. The Quarterly Journal of Economics, 110(4), 1127-1170.

Jayasuriya, D. (2011). Improvements in the World Bank's ease of doing business rankings: Do they translate into greater foreign direct investment inflows? World Bank Policy Research Working Paper 5787. https://doi.org/10.2139/ssrn.2040543

Karadam, D. Y. (2018). An investigation of nonlinear effects of debt on growth. Journal of Economic Asymmetries, 18, 1-13. https://doi.org/10.1016/j.jeca.2018.e00097

Kharusi, S. Al., \& Mbah, A. S. (2018). External debt and economic growth : The case of emerging economy. Journal of Economic Integration, 33(1), 1141-1157. https://doi.org/10.11130/jei.2018.33.1.1141

Kim, E., Ha, Y., \& Kim, S. (2017). Public debt, corruption and sustainable economic growth. Sustainability, 9(3), 433. https://doi.org/10.3390/su9030433

Kim, K., \& Pang, H. (2008). The impact of foreign direct investment on economic growth: A case study of Ireland. International Journal of Business and Social Science, 3(October).

Krstevska, A., \& Petrovska, M. (2012). The economic impacts of the foreign direct investment: Panel estimation by sectors on the case of Macedonian economy. Journal of Central Banking Theory and Practice, 2, 55-73.

Lucas, R. E. (1988). On the mechanics of economic development. Journal of Monetary Economics, 22(1), 3-42.

Mencinger, J., Verbic, M., \& Aristovnik, A. (2015). Revisiting the role of public debt in economic growth: The case of OECD countries. Engineering Economics, 26(1), 61-66.

Pegkas, P. (2018). The effect of government debt and other determinants on economic growth: The Greek experience. Economies, 6(1). https://doi.org/10.3390/economies6010010

Rana, E. A., \& Wahid, A. N. M. (2017). Fiscal Deficit and Economic Growth in Bangladesh. The American Economist, 62(1), 31-42. https://doi.org/10.1177/0569434516672778

Raza, M., Aldeehani, T. M., \& Alshebami, A. S. (2020). The relationship between domestic investment and quality economic growth in Thailand. International Journal for Quality Research, 14(3), 691-704.

Romer, P. M. (1986). Increasing returns and long-run growth. Journal of Political Economy, 94(5), 1002-1037.

Shahbaz, M., \& Rahman, M. M. (2012). The dynamic of financial development, imports, foreign direct investment and economic growth: Cointegration and causality analysis in Pakistan. Global Business Review, 13(2), 201-219.

Snowdon, B., \& Vane, H. R. (2005). Modern macroeconomics. United Kingdom: Edward Elgar Publishing Limited.

Solow, R. M. (1956). A contribution to the theory of economic growth. Quarterly Journal of Economics, 70(1).

Sulikova, V., Djukic, M., Gazda, V., Horvath, D., \& Kulhanek, L. (2015). Asymmetric impact of public debt on economic growth in selected EU countries. Ekonomicky Casopis, 63(9), 944-958.

The World Bank. (2018). World Bank analytical classifications. 


\section{INTERNATIONAL JOURNAL OF ACADEMIC RESEARCH ECONOMICS AND MANAGEMENT}

\section{SCIENCES}

Vol. 10, No. 1, 2021, E-ISSN: 2226-3624 @ 2021 HRMARS

Transparency International. (2018). Corruption perception index 2018: Gabon. Retrieved October 12, 2019, from https://www.transparency.org/country/GAB

Saini, W. A. W. N. (2009). Three empirical essays on foreign direct investment, research and development, and insurance. University of Southampton.

Zhang, Z., Hao, Y., Lu, Z. N., \& Deng, Y. (2018). How does demographic structure affect environmental quality? Empirical evidence from China. Resources, Conservation and Recycling, 133(February), 242-249. https://doi.org/10.1016/j.resconrec.2018.02.017

\section{Appendix}

\section{Appendix 1: List of countries within UMIE}

\begin{tabular}{|c|c|c|}
\hline Countries included & $\begin{array}{l}\text { 1. Albania } \\
\text { 2. Algeria } \\
\text { 3. Argentina } \\
\text { 4. Armenia } \\
\text { 5. Belize } \\
\text { 6. Botswana } \\
\text { 7. Brazil } \\
\text { 8. Bulgaria } \\
\text { 9. China } \\
\text { 10. Colombia } \\
\text { 11. Costa Rica } \\
\text { 12. Dominican Republic } \\
\text { 13. Ecuador } \\
\text { 14. Gabon } \\
\text { 15. Guatemala } \\
\text { 16. Islamic Republic of Iran }\end{array}$ & $\begin{array}{l}\text { 17. Jamaica } \\
\text { 18. Jordan } \\
\text { 19. Kazakhstan } \\
\text { 20. Malaysia } \\
\text { 21. Mauritius } \\
\text { 22. Mexico } \\
\text { 23. Paraguay } \\
\text { 24. Peru } \\
\text { 25. Romania } \\
\text { 26. Russian Federation } \\
\text { 27. Serbia } \\
\text { 28. South Africa } \\
\text { 29. Sri Lanka } \\
\text { 30. Thailand } \\
\text { 31. Turkey } \\
\text { 32. Venezuela }\end{array}$ \\
\hline $\begin{array}{l}\text { Countries } \\
\text { excluded due to } \\
\text { unavailability of } \\
\text { data }\end{array}$ & $\begin{array}{l}\text { 1. American Samoa } \\
\text { 2. Azerbaijan } \\
\text { 3. Belarus } \\
\text { 4. Belize } \\
\text { 5. Bosnia and Herzegovina } \\
\text { 6. Cuba } \\
\text { 7. Dominica } \\
\text { 8. Equatorial Guinea } \\
\text { 9. Fiji } \\
\text { 10. Guyana } \\
\text { 11. Grenada } \\
\text { 12. Iraq } \\
\text { 13. Lebanon } \\
\text { 14. Libya }\end{array}$ & $\begin{array}{l}\text { 15. Macedonia } \\
\text { 16. Maldives } \\
\text { 17. Marshall Islands } \\
\text { 18. Montenegro } \\
\text { 19. Namibia } \\
\text { 20. Nauru } \\
\text { 21. Samoa } \\
\text { 22. St. Lucia } \\
\text { 23. St. Vincent and the Grenadines } \\
\text { 24. Suriname } \\
\text { 25. Tonga } \\
\text { 26. Turkmenistan } \\
\text { 27. Tuvalu }\end{array}$ \\
\hline
\end{tabular}


INTERNATIONAL JOURNAL OF ACADEMIC RESEARCH ECONOMICS AND MANAGEMENT SCIENCES Vol. 10, No. 1, 2020, E-ISSN: 2226-3624 @ 2020 HRMARS

\section{Appendix 2: Scatter plots of INV2, SAV and FDI against $Y$}

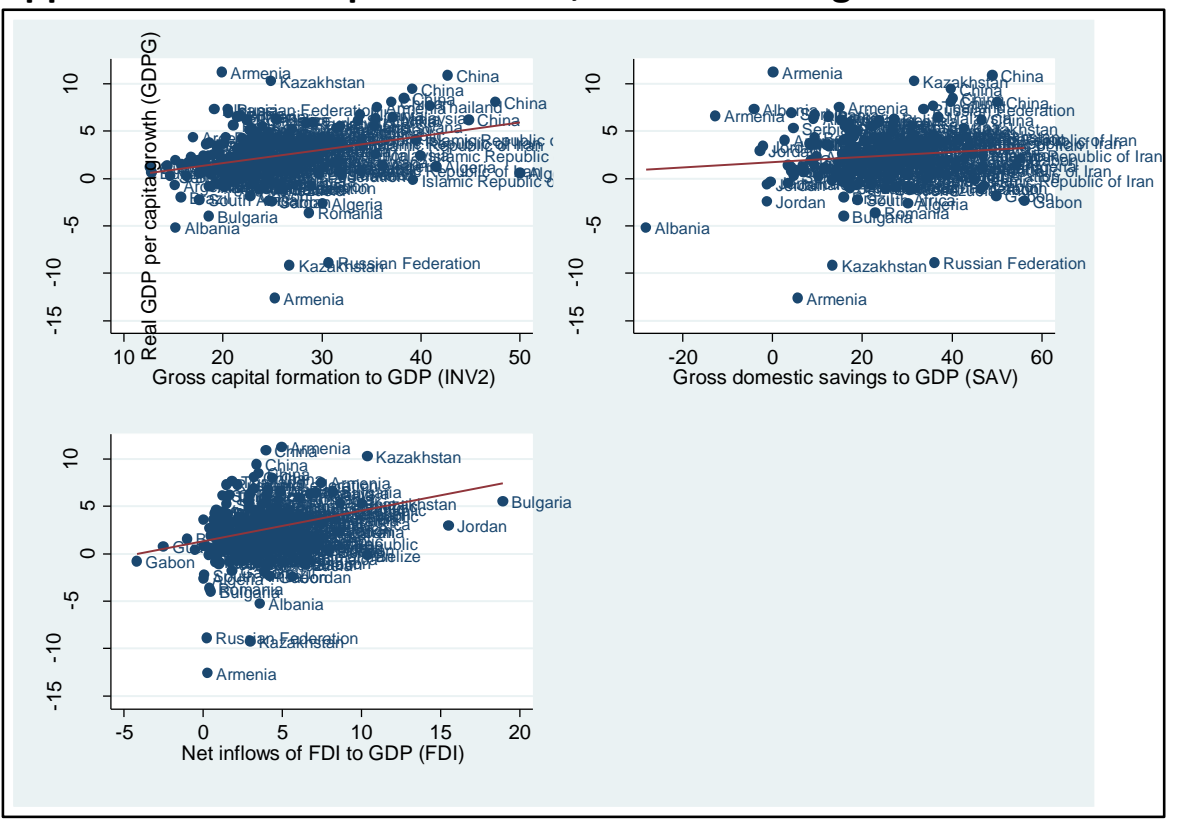

